\title{
Unraveling the effects of environmental drivers and spatial structure on benthic species distribution patterns in Eurasian-Arctic seas (Barents, Kara and Laptev Seas)
}

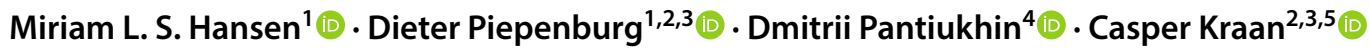

Received: 15 May 2020 / Revised: 14 August 2020 / Accepted: 27 August 2020 / Published online: 7 September 2020

(c) The Author(s) 2020

\begin{abstract}
In times of accelerating climate change, species are challenged to respond to rapidly shifting environmental settings. Yet, faunal distribution and composition are still scarcely known for remote and little explored seas, where observations are limited in number and mostly refer to local scales. Here, we present the first comprehensive study on Eurasian-Arctic macrobenthos that aims to unravel the relative influence of distinct spatial scales and environmental factors in determining their large-scale distribution and composition patterns. To consider the spatial structure of benthic distribution patterns in response to environmental forcing, we applied Moran's eigenvector mapping (MEM) on a large dataset of 341 samples from the Barents, Kara and Laptev Seas taken between 1991 and 2014, with a total of 403 macrobenthic taxa (species or genera) that were present in $\geq 10$ samples. MEM analysis revealed three spatial scales describing patterns within or beyond single seas (broad: $\geq 400 \mathrm{~km}$, meso: $100-400 \mathrm{~km}$, and small: $\leq 100 \mathrm{~km}$ ). Each scale is associated with a characteristic benthic fauna and environmental drivers (broad: apparent oxygen utilization and phosphate, meso: distance-to-shoreline and temperature, small: organic carbon flux and distance-to-shoreline). Our results suggest that different environmental factors determine the variation of Eurasian-Arctic benthic community composition within the spatial scales considered and highlight the importance of considering the diverse spatial structure of species communities in marine ecosystems. This multiple-scale approach facilitates an enhanced understanding of the impact of climate-driven environmental changes that is necessary for developing appropriate management strategies for the conservation and sustainable utilization of Arctic marine systems.
\end{abstract}

Keywords Multivariate community analysis $\cdot$ Environmental factors $\cdot$ Macrobenthos $\cdot$ Spatial structure $\cdot$ Moran’s eigenvector mapping $\cdot$ Eurasian-Arctic

Electronic supplementary material The online version of this article (https://doi.org/10.1007/s00300-020-02737-9) contains supplementary material, which is available to authorized users.

Miriam L. S. Hansen

mhansen@ecology.uni-kiel.de

1 Institute of Ecosystem Research, Christian Albrecht University of Kiel, 24118 Kiel, Germany

2 Helmholtz Centre for Polar and Marine Research (AWI), Alfred Wegener Institute, 27570 Bremerhaven, Germany

3 Helmholtz Institute for Functional Marine Biodiversity at the University of Oldenburg, 23129 Oldenburg, Germany

4 Institute of Earth Sciences, Saint Petersburg State University, St. Petersburg 199034, Russia

5 Institute of Sea Fisheries, Johann Heinrich Von Thünen Institute, 27572 Bremerhaven, Germany

\section{Introduction}

Understanding spatial patterns and temporal dynamics of biotic community structure and processes in relation to intrinsic factors and environmental forcing is a longstanding concern in ecology (Legendre 1993). Particularly, gaining insight in the spatial distribution of species, which is not random but largely determined by intrinsic biotic properties (population demography, behavioral traits, and interspecific interactions) and external forcing (regionally heterogeneous environmental conditions) remains a challenge (Dray et al. 2012). As in all oceans, warming, acidification and shifting circulation patterns are key consequences of climate change in Arctic seas. In addition, anthropogenic activities, including fossil-fuel extraction, industrial emissions, shipping and tourism, are constantly growing and exerting mounting pressures on 
marine ecosystems (Doney et al. 2012; Solovyev et al. 2017). The reduction of sea ice, which is one of the most obvious effects of warming in polar regions, and the alterations of its dynamics lead to large-scale changes in the environmental conditions of Arctic seas, with cascading impacts on marine ecosystems (Macias-Fauria and Post 2018). This includes the composition and spatial distribution of benthic communities (Doney et al. 2012), the knowledge of which is of high value for environmental protection efforts (Sirenko 2001). Generally, benthic biotas are important for the overall functioning of marine ecosystems, as they decompose organic material, contribute to nutrient cycling and serve as food source for higher trophic levels (Silberberger et al. 2018). Changing environmental conditions can lead to shifts in benthic communities, such as composition and distribution, and may impact ecosystem functions (Carroll et al. 2008; CAFF 2017). Ice cover, bathymetry, water temperature, salinity, and sediment properties are considered the environmental drivers that are most influential in determining benthic biodiversity patterns and processes (Vedenin et al. 2015), while fisheries, persistent contaminants, industrial development and shipping are key anthropogenic drivers (Yasuhara et al. 2012; CAFF 2017).

Community structure varies among every existent spatial scale (broad, intermediate, and small) and is absolutely independent of organism size. Each spatial scale displays a characteristic composition of driving environmental processes and fauna. Roy et al. (2014) provide an exception to this statement in their study about the Canadian epibenthos by suggesting that there is no large regional difference in benthic community characteristics. A number of studies have revealed the importance of considering spatial scales in understanding the causes of species distributions by suggesting that ecological processes operate on multiple spatial scales and thus structure distinct aspects of species communities (Levin 1992; Bellier et al. 2007; Ingels and Vanreusel 2013; Silberberger et al. 2018; Gutt et al. 2019). However, spatial scales have rarely explicitly been considered in large-scale Arctic studies, which focused rather on providing inventories of Arctic benthic biodiversity and identifying knowledge gaps (Bluhm et al. 2011; Piepenburg et al. 2011; Renaud et al. 2015). Furthermore, as sampling data for multi-scale statistical analyses are very timeconsuming and expensive, this field of research has only been scarcely investigated (Yasuhara et al. 2012). While there are several studies on local community structures in Arctic seas, few addressed explicitly multiple spatial scales in their analysis, e.g., in the Fram Strait (Budaeva et al. 2008), in the Barents Sea (Carroll et al. 2008), the Chukchi Sea (Blanchard and Feder 2014) or around the sub-Arctic Lofoten-Vesterålen islands (Silberberger et al. 2016, 2018). A comprehensive community analysis over several Arctic seas, including the consideration of environmental drivers and a range of spatial scales, is still scarce (Roy et al. 2014).

Inventories of marine benthic fauna in the Russian Arctic have already begun at the end of the eighteenth century and have been updated regularly (e.g., Zenkevitch 1963; Sirenko and Piepenburg 1994; Sirenko 2001; Bluhm et al. 2011; Piepenburg et al. 2011; Renaud et al. 2015). Additionally, there are studies concentrating on benthic biodiversity in the different Eurasian-Arctic seas, such as the Barents (Cochrane et al. 2009; Jirkov 2013), Kara (Jørgensen et al. 1999; Deubel et al. 2003; Galkin and Vedenin 2015; Vedenin et al. 2015), Laptev (Sirenko et al. 2004; Kokarev et al. 2017) and the East Siberian Seas (Spiridonov et al. 2011). Moreover, biogeographical regionalization efforts of benthic fauna were conducted that allowed the classification of faunal species into distinct groups, such as Boreal or Atlantic subareas, and thus deliver a further evaluation of the Eurasian-Arctic marine ecosystem (Zenkevitch 1963; Spiridonov et al. 2011). However, to advance from basic regional classifications, we make use of Moran's eigenvector mapping (Dray et al. 2006), to reveal spatial categorizations of macrobenthic species groups and evaluate the specific impact of certain environmental drivers on faunal distribution patterns.

The specific objectives of this study were (a) detect characteristic spatial scales of benthic distribution patterns across a range of Eurasian-Arctic seas and uncover the regional distribution of the taxonomic groups in the study area, (b) identify which taxa are associated with which distinct scale, (c) assess the relative importance of environmental drivers of benthic communities at different spatial scales, and (d) assess the relative contributions of environmental factors versus spatial structure in determining the composition of benthic assemblages. This work shall add a further valuable piece of information to the global pool of existing knowledge about species-environment interdependencies in the sensitive Arctic region and help to design and implement solid science-based conservation strategies.

\section{Materials and methods}

\section{Study region}

The area considered for our study ranges from $68^{\circ} \mathrm{N}$ and $16^{\circ} \mathrm{E}$ to $82^{\circ} \mathrm{N}$ and $150^{\circ} \mathrm{E}$ and encompasses the Barents (including the waters around Svalbard: $81.57^{\circ} \mathrm{N} 15.41^{\circ}$ $\mathrm{E}$ and $\left.68.60^{\circ} \mathrm{N} 51.00^{\circ} \mathrm{E}\right)$, Kara $\left(81.57^{\circ} \mathrm{N} 52.30^{\circ} \mathrm{E}\right.$ and $\left.68.60^{\circ} \mathrm{N} 105.40^{\circ} \mathrm{E}\right)$ and Laptev $\left(81.57^{\circ} \mathrm{N} 107.24^{\circ} \mathrm{E}\right.$ and $68.60^{\circ} \mathrm{N} 149.46^{\circ}$ E) Seas (Fig. 1). The majority of the Arctic continental shelves is very broad with average depths between less than $200 \mathrm{~m}$ in the Kara Sea (Zenkevitch 1963), $230 \mathrm{~m}$ in the Barents Sea (Jirkov 2013), and $533 \mathrm{~m}$ in the 


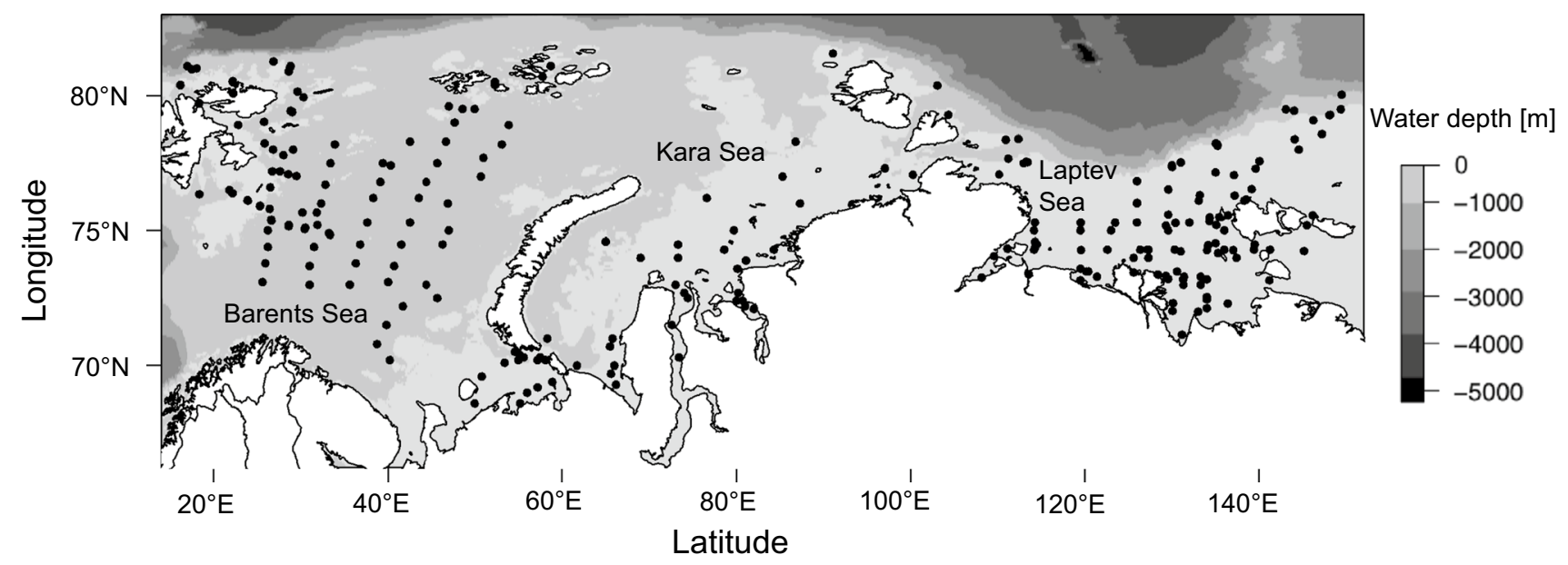

Fig. 1 Map of the Eurasian-Arctic study area (Barents, Kara, and Laptev Seas). Black dots indicate the geographic location of 341 sampling stations at water depths $<1000 \mathrm{~m}$ : in the Barents Sea + Svalbard $(n=145)$, Kara Sea $(n=38)$ and Laptev Sea $(n=158)$

Laptev Sea (Spiridonov et al. 2011). The water column in Arctic seas usually exhibits a pronounced stratification as a result of freshwater inflow from ice melting and river discharge (CAFF 2017), particularly in the Kara and Laptev Seas, which receive $1,700 \mathrm{~km}^{3}$ of freshwater per year from the rivers $\mathrm{Ob}$, Yenisei and Lena (Vedenin et al. 2018). Between these and other Arctic rivers, like Kolyma, Pechora and Northern Dvina, large sediment loads and terrestrial organic matter are transported to the seas (Gordeev et al. 1996; Bluhm et al. 2011). Ocean currents from the Atlantic and Pacific cause mixing and exchanging processes of, e.g., nutrients, organic matter, and larvae of invertebrate species. The Atlantic feeds huge amounts of warm and salty water masses via the broad opening of the Fram Strait to the Arctic Ocean, which is supposed to affect benthic ecosystems in the study area (Rudels 2012; CAFF 2017). The Pacific Ocean supplies less warm and less salty water via the narrow Bering Strait in the Eastern Arctic, which makes it less important to the fauna in our study area (Woodgate 2018). The structure of the water column can be subdivided into three layers: an upper mixed layer which is relatively warm with temperatures of up to $12{ }^{\circ} \mathrm{C}$ and least saline, an intermediate layer with Atlantic warm and saline water and a deep Arctic layer which is colder (between 0 and $-1{ }^{\circ} \mathrm{C}$ ) and more saline (between 34.9 and 35.0) (Steele et al. 2008; Rudels 2012; Woodgate 2018). The Arctic seabed consists mainly of silt and clay with the exception of drop stones providing hard substrata as habitat and ridges and plateaus which exhibit higher loads of sand (Bluhm et al. 2011).

\section{Biotic data}

The data used in our analysis contained information on the presence of macrobenthic taxa (organisms larger than
$0.5 \mathrm{~mm}$ ) in grab samples (box corer, Petersen grab or van Veen grab, with sampling areas from $0.1 \mathrm{~m}^{2}$ to $0.25 \mathrm{~m}^{2}$ ) taken at a total of 341 stations in the Barents Sea + Svalbard area (145), Kara Sea (38) or Laptev Sea (158) (Fig. 1) visited in the course of 16 scientific cruises during summer (May-October) between 1991 and 2014 (Online Resource $1)$. The data were not taken by us, but compiled from publicly available data platforms. The prime reason why we decided to analyze presence/absence data is because they are more robust to bias introduced by varying sampling effort than quantitative data. Our biotic data rely on grab samples, which generally cannot be obtained from sandy and gravelly areas and thus are not considered in our study. Accordingly, our macrobenthic species are mainly infaunal communities as they are represented in grab samples. Sampling locations are situated approximately between 4 and $700 \mathrm{~km}$ off the coastline and at water depths less than $1000 \mathrm{~m}$ (Fig. 1). To clean and properly prepare our data for analysis, we followed the suggestions presented by Piepenburg et al. (2011). We used only those 403 macrobenthic taxa (from a total of 2,087 ) that (a) were identified to species or genus level and (b) occurred at least at ten sampling stations in the study area, to reduce the stochastic noise introduced by the random occurrence of 'rare' species in our data, which would bias the detection of spatial patterns. Taxonomic information was validated via the World Register of Marine Species (WoRMS; https://www.marinespecies.org/) to avoid the use of synonyms and outdated scientific names.

\section{Environmental data}

For our analysis, we considered 12 environmental parameters to be relevant as potential drivers of the distribution patterns of macrobenthic species in our study region 
Table 1 List of environmental variables, units and data sources used in the analysis of presence data of 403 macrobenthic taxa (species or genera) identified in grab samples taken at a total of 341 stations in the Barents, Kara, and Laptev Seas during summers (May-October) between 1991 and 2014

\begin{tabular}{|c|c|c|}
\hline Variable & Unit & Data source \\
\hline Sea-ice Cover & $\%$ & https://nsidc.org/data/g10010\# \\
\hline Water depth & $\mathrm{m}$ & $\begin{array}{l}\text { https://www.gebco.net/news_and_media/version_3_ } \\
\text { ibcao_release.html }\end{array}$ \\
\hline Temperature & ${ }^{\circ} \mathrm{C}$ & https://www.nodc.noaa.gov/OC5/woa18/ \\
\hline Salinity & PSU & https://www.nodc.noaa.gov/OC5/woa18/ \\
\hline Silt and clay & $\%$ & https://doi.pangaea.de/10.1594/PANGAEA.909392 \\
\hline Distance to shore & $\mathrm{km}$ & https://gmed.auckland.ac.nz \\
\hline Dissolved oxygen & $\mu \mathrm{mol} \mathrm{kg}-1$ & https://www.nodc.noaa.gov/OC5/woa18/ \\
\hline Organic carbon flux & $\mathrm{G} \mathrm{m}^{-2}$ year $^{-1}$ & https://www.science.oregonstate.edu/ocean.productivity/ \\
\hline Slope of seafloor & $\circ$ & https://gmed.auckland.ac.nz \\
\hline Nitrate & $\mu \mathrm{mol} \mathrm{kg}-1$ & https://www.nodc.noaa.gov/OC5/woa18/ \\
\hline Phosphate & $\mu \mathrm{mol} \mathrm{kg}-1$ & https://www.nodc.noaa.gov/OC5/woa18/ \\
\hline Apparent oxygen utilization & $\mu \mathrm{mol} \mathrm{kg}{ }^{-1}$ & https://www.nodc.noaa.gov/OC5/woa18/ \\
\hline
\end{tabular}

(Table 1). For each parameter, we extracted monthly average values corresponding to the place and time of sampling of the biological data. We intentionally ignored the environmental data actually measured during the respective sampling cruises, since those are mainly snapshot measurements. Moreover, for many stations there was no environmental information available from the cruises, so we used uniform datasets for all stations from publicly accessible databases. The International Bathymetric Chart of the Arctic Ocean (IBCAO; Jakobsson et al. 2012) provided water-depth data. From the National Snow and Ice Data Center (NSIDC), we obtained monthly Arctic seaice cover values (Walsh et al. 2017). Slope of the seafloor and distance to shore of each sampling location were retrieved from the Global Marine Environment Dataset (GMED; Basher et al. 2018). The World Ocean Atlas 2018 (WOA18; Garcia et al. 2018a, b; Locarnini et al. 2018; Zweng et al. 2018) provided information on bottom-water temperature and salinity, apparent oxygen utilization, dissolved oxygen, as well as near-bottom concentrations of phosphate and nitrate. Point data on the percentages of silt and clay in bottom sediments were retrieved from Pantiukhin et al. (2019). For estimating the organic carbon flux to the seafloor, using the empirical function proposed by Suess (1980), data on primary production were taken from the Ocean Productivity website of Oregon State University (https://www.science.oregonstate.edu/ocean) and compiled using a Carbon-based Productivity Model by Behrenfeld et al. (2005). All environmental data layers were transferred to a unified raster graphical format with the coordinate system WGS84 and rescaled using bilinear interpolation to have the same spatial dimension $(67 \times 552$ pixels), extent (longitude between $14^{\circ} \mathrm{E}$ and $152^{\circ} \mathrm{E}$; latitude between $66.2^{\circ} \mathrm{N}$ and $\left.83^{\circ} \mathrm{N}\right)$ and latitudinal/longitudinal resolution $\left(0.25^{\circ} \times 0.25^{\circ}\right)($ Online Resource 3$)$. The reliability of data varies among variables and scales due to the distinct databases we used for data retrieval. This introduces a certain bias into the analysis, which cannot be quantified or avoided.

\section{Multivariate spatial analysis}

To determine the spatial structure in community and environmental data, a variety of multivariate modeling approaches, such as multi-scale pattern analysis (MSPA), spatial eigenfunctions or linear model of coregionalization (LMC), have been developed (Bellier et al. 2007; Jombart et al. 2009; Dray et al. 2012; Legendre and Legendre 2012). The goal of these models is to understand distributional patterns by detecting and identifying characteristic spatial scales and unraveling the relative importance of spatial distance vs. environmental forcing in explaining the spatial variation of community composition (Dray et al. 2012). Borcard and Legendre (2002) introduced the method of principal coordinates of neighbor matrices (PCNM), which in a generalized form is called Moran's eigenvector mapping (MEM; Dray et al. 2006, 2012). These methods are eigenfunction-based and process two types of information: binary information about whether two sampling locations are connected or not and information indicating how strong the above-mentioned connection is (Legendre and Legendre 2012).

We used Moran's eigenvector mapping (MEM) for the concomitant analysis of community composition, spatial structure, and environmental variables. MEM describes the different spatial scales prevailing in the distribution patterns of both the biotic communities and environmental factors. It also identifies taxa which are particularly associated with each distinct spatial scale. MEM considers implicitly the spatial distances between sampling stations in contrast to other methods which ignore this important regional feature. Moran's eigenvectors are centered, scaled, orthogonal and uncorrelated, all of which are excellent properties 
for multi-scale spatial predictors (Jombart et al. 2009). The basic approach of MEM analysis is that spatial distances between sampling locations can be transformed into explanatory variables containing specific information about the relationships at different spatial scales (Peres-Neto and Legendre 2010).

Creating the spatial weighting matrix (SWM), which describes the specific relationship between sampling sites, is the most crucial step of the MEM analysis. The SWM influences the accuracy of parameter estimation and the spatial patterns that can be detected with the model (Bauman et al. 2018). The SWM actually features two separate matrices: a binary connectivity matrix that indicates which sampling sites are geographically linked (1) and which are not (0), and a weighting matrix that contains information about the intensity of the connection between sites (Dray et al. 2006; Borcard et al. 2011; Legendre and Legendre 2012). The weighting values of the spatial links can be calculated by functions of spatial distances, least-cost links between the sampling sites or other measures (Dray et al. 2012). We tested Delaunay triangulation, Gabriel graph, relative neighborhood graph, and minimum spanning tree (Dray et al. 2006; Borcard et al. 2011). The criteria for choosing the optimal SWM was a high level of $A d j R^{2}$ for the connectivity matrix candidates. In our case the nearest neighbor matrix best captured the connectivity between sampling sites with the highest $\operatorname{Adj}^{2}$ of $24.61 \%$.

Based on the chosen SWM, we calculated the spatial eigenvalues, also called MEM variables. Since we were only interested in eigenfunctions that represented positive autocorrelations, we ran a forward selection at 999 permutations with $\alpha=0.05$ and received 49 significant MEM variables. Out of these 49 variables, 17 MEM variables displayed spatial patterns (Table 2). Correlograms were used to identify the spatial scale that each of the 17 MEM variables captures. Then, based on the similarity of their range, these variables were categorized into variable groups representing the different spatial scales that structure the community composition in the study area (Benedetti-Cecchi et al. 2010). We used forward selection to determine significant environmental variables, using a double-stopping criterion: the alpha significance level of 0.05 and the adjusted coefficient of multiple determination $\left(A d j R^{2}\right)$ calculated using all environmental variables (Blanchet et al. 2008; Borcard et al. 2011). Afterwards, we ran a redundancy analysis (RDA) to identify and rank those variables that explained most of the variation in the community data (Legendre and Legendre 2012). Forward selection and RDA were also applied to identify the associated macrobenthic fauna for each spatial scale.

Finally, we used variation partitioning to determine the shares of spatial distances and environmental factors in the explanation of spatial community patterns (Borcard et al. 1992; Peres-Neto et al. 2006; Peres-Neto and Legendre
Table 2 List of significant Moran's eigenvector mapping (MEM) variables identified in the analysis of presence data of 403 macrobenthic taxa (species or genera) identified in grab samples taken at a total of 341 stations in the Barents, Kara, and Laptev Seas during summers (May-October) between 1991 and 2014 and categorized into broad ( $\geq 400-\mathrm{km})$, meso $(100-400-\mathrm{km})$ and small $(\leq 100-\mathrm{km})$ scales

\begin{tabular}{llc}
\hline Scale & MEM variable & Range in $\mathrm{km}$ \\
\hline Small & 49 & 54.2 \\
& 25 & 54.5 \\
Meso & 33 & 146.1 \\
& 28 & 166.5 \\
& 24 & 170.5 \\
& 44 & 175.4 \\
& 30 & 179.4 \\
& 20 & 183.3 \\
& 23 & 230.0 \\
& 22 & 236.2 \\
& 34 & 253.1 \\
& 19 & 297.5 \\
& 21 & 314.5 \\
& 9 & 347.5 \\
& 18 & 528.1 \\
& 13 & 731.3 \\
& 15 & 839.3 \\
\hline
\end{tabular}

2010). It calculates the variation in separate fractions, i.e., the variation explained by spatial distance alone, the variation explained by environmental variables alone, the variation explained by both spatial distance and environmental variables jointly, as well the fraction of unexplained variation (Borcard et al. 2011).

Statistical analysis was conducted in $R$ version 3.4.1 ( $\mathrm{R}$ Development Core Team 2017), using the packages adespatial (Dray et al. 2019) and vegan (Oksanen et al. 2018).

\section{Results}

\section{Spatial scales and regional distribution of taxonomic groups}

According to MEM analysis the distribution of macrobenthic fauna in Eurasian-Arctic seas showed distinct features at spatial scales of $\geq 400 \mathrm{~km}$ (broad), $100-400 \mathrm{~km}$ (meso), and $\leq 100 \mathrm{~km}$ (small) (Table 2, Online Resource 4). MEM detected the smallest spatial distance at $54 \mathrm{~km}$ and the largest distance at $839 \mathrm{~km}$ (Table 2).

The investigated taxa are from a broad variety of phyla, e.g., sponges, crustaceans, bivalves, polychaetes, gastropods, and echinoderms. The most frequent species, the polychaete Terebellides stroemii, was present at more than $50 \%$ of the sampling sites $(57 \% ; n=196)$ (Online Resource 
2). Macrobenthic fauna can be categorized into 24 taxonomic groups. In the region of Svalbard and the Barents Sea, a total of 383 taxa from 24 taxonomic groups were recorded. The Kara Sea housed 358 taxa from 23 different taxonomic groups, and the Laptev Sea a total of 291 taxa from 18 taxonomic groups (Fig. 2; Online Resource 5). The community composition on class level was largely similar among all three regions with polychaetes, malacostracans, bivalves, bryozoans (Gymnolaemata) and gastropods being most frequent.

\section{Macrobenthic taxa associated to spatial scales}

Of the 403 macrobenthic taxa considered in our data in total, the distribution of 170 taxa showed significant structuring on at least one of the three spatial scales identified in the MEM analysis. For 50 taxa, this was evident on the $\geq 400$ $\mathrm{km}$ scale, for 90 taxa on the 100-400-km scale, and for 62 on the $\leq 100-\mathrm{km}$ scale (Table 3; Online Resource 6). With

(a) Whole study area [403]

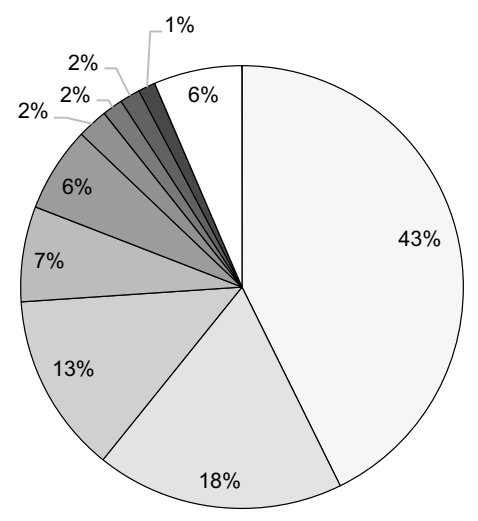

(c) Kara Sea [358]

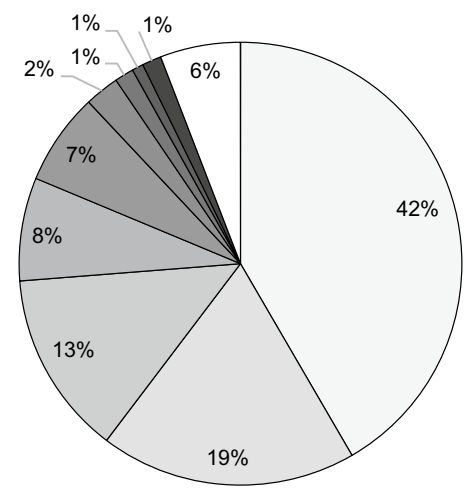

口Polychaeta $\square$ Malacostraca $\square$ Bivalvia $\square$ Gymnolaemata $\square$ Gastropoda 口Ophiuroidea $\square$ Stenolaemata $\square$ Sipunculidea $\square$ Holothuroidea $\square$ other groups

Fig. 2 Percentages of taxonomic classes in the total number of macrobenthic taxa (species or genera) used in the analysis of presence data of 403 macrobenthic taxa identified in grab samples taken at a total of 341 stations in the whole study area (a), the Barents (b), Kara a few exceptions, the composition of macrobenthic assemblages among the different scales were highly variable. The distribution of only a few taxa exhibited significant spatial patterns on more than one scale, and their ranking varied across scales. Of the 128 taxa showing significant spatial structuring at the broad or mesoscales, only $9(7 \%)$ were associated with both scales. Of the 103 taxa that showed spatial structuring at the broad and small scales, only 6 (5.8\%) were associated with both scales and of the 137 taxa showing significant spatial structuring on the meso and small scale, 12 taxa (8.8\%) were associated with both scales (Online Resource 6). Only three species, the polychaetes Cirrophorus branchiatus and Lumbriclymene cylindricauda and the gymnolaemata Porella sp. displayed a significant association with all three spatial scales, suggesting that they are widely distributed in the study area.

(b) Barents Sea + Svalbard [383]

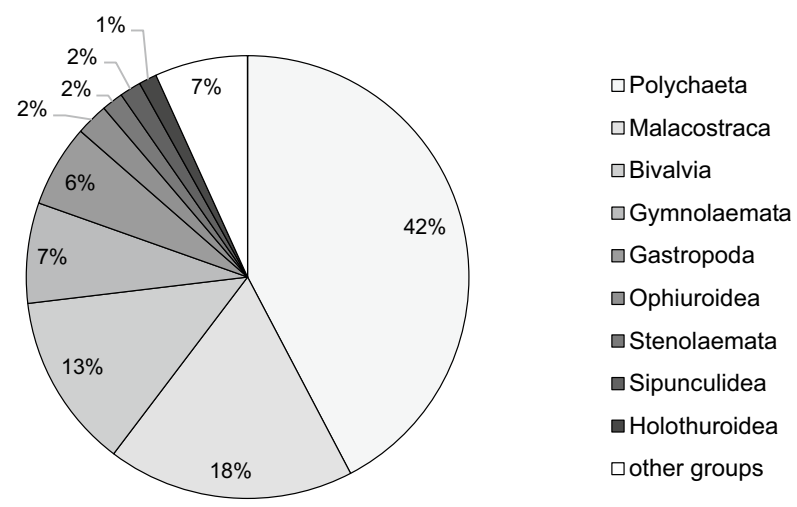

(d) Laptev Sea [291]

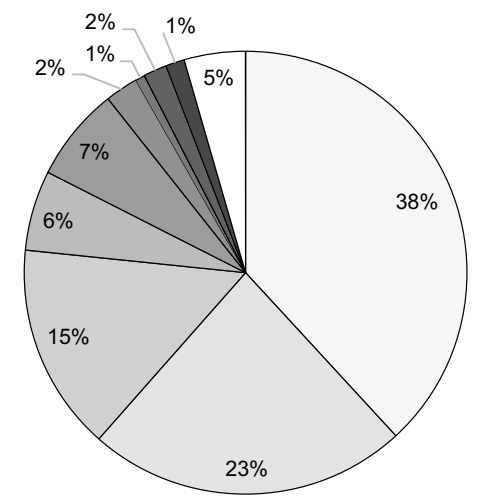

$\square$ Polychaeta $\square$ Malacostraca $\square$ Bivalvia $\square$ Gymnolaemata $\square$ Gastropoda 口Ophiuroidea $\square$ Stenolaemata $\square$ Sipunculidea $\square$ Holothuroidea 口other groups

(c), and Laptev (d) Seas during summers (May-October) between 1991 and 2014. Total number of taxa found in the entire study area and the three seas are given in square brackets. See Online Resource 5 for the entire dataset 
Table 3 Rank list of taxa (species or genera) used in the analysis of presence data of 403 macrobenthic taxa identified in grab samples taken at a total of 341 stations in the Barents, Kara, and Laptev Seas during summers (May-October) between 1991 and 2014

\begin{tabular}{|c|c|c|c|c|c|c|}
\hline \multirow[b]{2}{*}{ Order } & \multicolumn{2}{|l|}{$\geq 400-\mathrm{km}$ scale } & \multicolumn{2}{|l|}{$100-400-\mathrm{km}$ scale } & \multicolumn{2}{|l|}{$\leq 100-\mathrm{km}$ scale } \\
\hline & Taxon & $\operatorname{Adj} R^{2}$ cum & Taxon & $\operatorname{Adj} R^{2}$ cum & Taxon & $\operatorname{Adj} R^{2}$ cum \\
\hline 1 & Portlandia arctica & 0.079 & Leitoscoloplos mammosus & 0.088 & Antinoella sp. & 0.093 \\
\hline 2 & Pholoe inornata & 0.152 & Parathyasira dunbari & 0.123 & Rhodine gracilior & 0.134 \\
\hline 3 & Chaetozone sp. & 0.210 & Aplacophora sp. & 0.151 & Ctenodiscus crispatus & 0.179 \\
\hline 4 & Ctenodiscus crispatus & 0.238 & Myrianida sp. & 0.178 & Schistomeringos sp. & 0.216 \\
\hline 5 & Dacrydium vitreum & 0.261 & Pionosyllis sp. & 0.196 & Parathyasira dunbari & 0.305 \\
\hline 6 & Ampharete acutifrons & 0.279 & Cossura sp. & 0.213 & Diastylis rathkei & 0.333 \\
\hline 7 & Cirrophorus branchiatus & 0.296 & Photis reinhardi & 0.226 & Euchone papillosa & 0.357 \\
\hline 8 & Eteone longa & 0.310 & Spio armata & 0.239 & Diastylis sp. & 0.377 \\
\hline 9 & Stenosemus albus & 0.325 & Paradoneis eliasoni & 0.251 & Ophiacantha bidentata & 0.396 \\
\hline 10 & Maldane arctica & 0.338 & Yoldiella lenticula & 0.263 & Balanus sp. & 0.413 \\
\hline
\end{tabular}

For each spatial scale identified in Moran's eigenvector mapping (MEM) analysis, taxa are ranked according to their contribution to the variation of macrobenthic community composition at $\geq 400-\mathrm{km}$ (broad), 100-400-km (meso) and $\leq 100-\mathrm{km}$ (small) scales. AdjR $R^{2}$ cum represents the cumulative share of this variation explained by the MEM model. For each scale, only the upper ten taxa contributing most to the variation are listed (see Online Resource 6 for a complete list)

\section{Environmental drivers}

All environmental variables used for the analysis appear as significant drivers on at least one of the detected spatial scales. On the $\geq 400-\mathrm{km}$ scale, apparent oxygen utilization was identified as the major environmental factor structuring benthic assemblages (AdjR $R^{2}$ of $15 \%$ ), followed by near-bottom phosphate content (11.9\%; Table 4). Eight of 12 environmental variables were found to be significant, together explaining a total of $33.9 \%$ ( $\operatorname{AdjR}^{2} \mathrm{Cum}$ ) of community variation. On the 100-400-km scale, we found distance to shore $\left(\operatorname{AdjR}^{2}\right.$ of $\left.3.8 \%\right)$ and temperature (3\%) to be the environmental parameters for explaining most of the benthic community composition (Table 4). Except for oxygen and phosphate, all of the environmental parameters contributed significantly to the explanatory power of the model (AdjR $R^{2}$ cum of $18.9 \%$ ). On the $\leq 100-\mathrm{km}$ scale, the community variation was significantly correlated with five environmental factors, out of which organic carbon flux possessed the highest explanatory power with an $A d j R^{2}$ of $4.1 \%$, followed by distance to shore (2.4\%; Table 4). The redundancy analysis showed that the five significant environmental variables explained 9.9\% $\left(\operatorname{Adj} R^{2}\right.$ cum $)$ of the total variation in benthic community variation on this scale.

Table 4 Redundancy analysis of presence data of 403 macrobenthic taxa (species or genera) identified in grab samples taken at a total of 341 stations in the Barents, Kara, and Laptev Seas during summers (May-October) between 1991 and 2014

\begin{tabular}{|c|c|c|c|c|c|c|c|c|c|}
\hline \multirow[b]{2}{*}{ Order } & \multicolumn{3}{|l|}{$\geq 400-\mathrm{km}$ scale } & \multicolumn{3}{|l|}{$100-400-\mathrm{km}$ scale } & \multicolumn{3}{|l|}{$\leq 100-\mathrm{km}$ scale } \\
\hline & Variables & $\operatorname{Adj} R^{2}$ cum & $p$-value & Variables & $\operatorname{Adj} R^{2}$ cum & $p$-value & Variables & $\operatorname{Adj} R^{2}$ cum & $p$-value \\
\hline 1 & App. oxygen utilization & 0.1505 & 0.0001 & Distance to shore & 0.0347 & 0.0001 & Organic carbon flux & 0.0413 & 0.0001 \\
\hline 2 & Phosphate & 0.2694 & 0.0001 & Temperature & 0.0688 & 0.0001 & Distance to shore & 0.0652 & 0.0003 \\
\hline 3 & Nitrate & 0.2866 & 0.0001 & Organic carbon flux & 0.0909 & 0.0001 & Slope of seafloor & 0.0796 & 0.014 \\
\hline 4 & Temperature & 0.2975 & 0.0003 & Nitrate & 0.1108 & 0.0001 & Silt and clay & 0.0905 & 0.0076 \\
\hline 5 & Salinity & 0.3253 & 0.0001 & App. oxygen utilization & 0.1272 & 0.0001 & Dissolved oxygen & 0.099 & 0.0407 \\
\hline 6 & Ice cover & 0.3308 & 0.0196 & Ice cover & 0.1458 & 0.0001 & - & - & - \\
\hline 7 & Organic carbon flux & 0.3348 & 0.0269 & Water depth & 0.1604 & 0.0001 & - & - & - \\
\hline 8 & Distance to shore & 0.3391 & 0.0301 & Salinity & 0.1721 & 0.0002 & - & - & - \\
\hline 9 & - & - & - & Slope of seafloor & 0.1809 & 0.0003 & - & - & - \\
\hline 10 & - & - & - & Silt and clay & 0.1887 & 0.0001 & - & - & - \\
\hline
\end{tabular}

For each spatial scale identified in Moran's eigenvector mapping (MEM) analysis, the environmental variables are shown that significantly $(p<0.05)$ contributed to explaining macrobenthic community patterns at $\geq 400-\mathrm{km}$ (broad), 100-400-km (meso) and $\leq 100-\mathrm{km}$ (small) scales. $A d j R^{2}$ cum represents the cumulative share of the variation in macrobenthic community composition explained by the model. Environmental variables are ranked for each scale according to their $A d j R^{2}$ value 


\section{Environmental forcing vs. spatial distance}

Overall, variation partitioning revealed that both spatial distances among sampling locations and environmental variables considered in our study explained part of the overall variation in the community data, ranging from $17.3 \%$ for the $\leq 100-\mathrm{km}$ scale to $23.3 \%$ across all spatial scales (Fig. 3). The relative importance of spatial distance vs. environmental forcing varied among spatial scales. While across all scales, spatial distance was slightly more relevant than environment, indicated by $\operatorname{AdjR}^{2}$ cum values of $6.7 \%$ vs. $5.3 \%$ (Fig. 3a), environmental forcing was consistently more important than spatial distance for all separate spatial scales, i.e., $\geq 400-\mathrm{km}$ scale: $11.3 \%$ vs. $0.8 \%$ (Fig. 3b); 100-400-km scale: $11.7 \%$ vs. $5.2 \%$ (Fig. 3 c); $\leq 100-\mathrm{km}$ scale: $16 \%$ vs. $0.7 \%$ (Fig. 3 d). The variation proportions that were explained jointly by both environmental variables and spatial distance ranged from $0.6 \%$ on the small $\leq 100-\mathrm{km}$ scale to $11.3 \%$ across all spatial scales (Fig. 3).

(a)

All scales

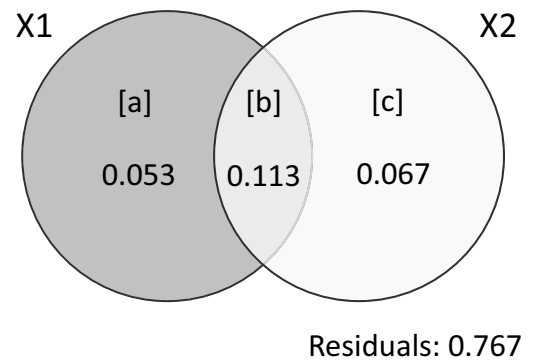

(c) $\quad 100-400-\mathrm{km}$ scale

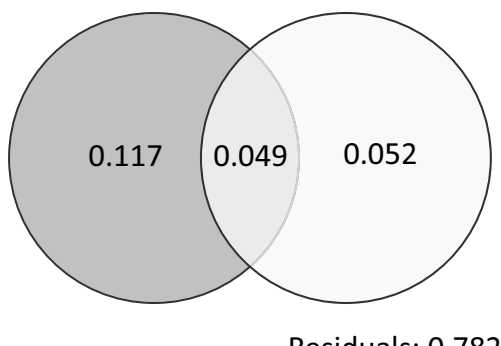

Residuals: 0.782

\section{Discussion}

In the Laptev Sea, despite the largest number of sampling locations $(n=158)$, we discern the smallest number of benthic species $(n=291)$ among the three investigated seas. This finding relates to the transport of Atlantic species by deep waters that do not reach the Eastern Russian Seas, due to the boundary islands of Severnaya Zemlya (Dilman 2009; Spiridonov et al. 2011). Pacific species generally play a minor role in the composition of Arctic communities, since they reach mainly the Chukchi Sea and only marginally the eastern part of the Laptev Sea (Sirenko 2001). The characteristic composition of benthic communities in the Russian Arctic is related to the bottom sediment composition, the productivity of the ecosystem, the individual location in the shelf zones and the extent of water exchange with the Atlantic or Pacific Ocean and with the adjacent seas and river runoffs (Sirenko and Piepenburg 1994; Sirenko 2009). The presence of estuarine bivalves and crustaceans prevails closer to river outfalls like the Lena Delta in the Laptev Sea or the $\mathrm{Ob}$ and Yenisei that flow into the Kara Sea. In greater depths

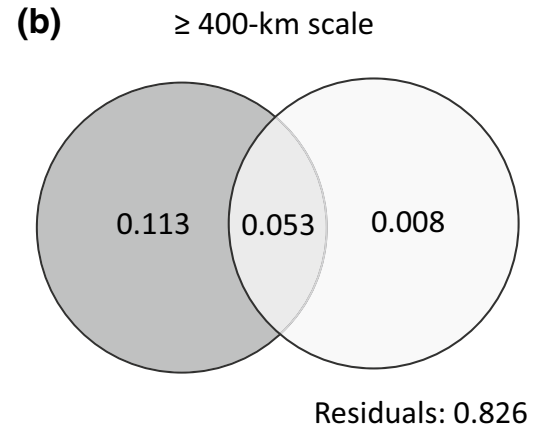

(d) $\quad \leq 100-\mathrm{km}$ scale

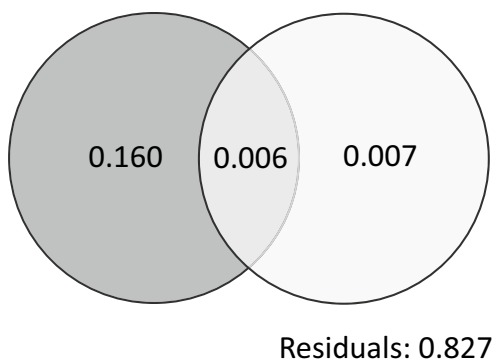

tion explained by environmental variables, X2 (light gray circles) the variation explained by spatial distance. Area $[a]=$ share of variation explained by environmental variables alone; area $[\mathrm{c}]=$ share of variation explained by spatial distance alone; area $[\mathrm{b}]=$ share of variation explained by both environmental variables and spatial distance. Numbers given in [a], [b] and [c] are $A d j R^{2}$ cum values representing percentages of the relative importance of spatial distance vs. environmental forcing 
of $600 \mathrm{~m}$ up to $2500 \mathrm{~m}$ the communities are dominated by the occurrence of ophiurans, polychaetes, holothurians and echinoderms (Spiridonov et al. 2011). The species most associated on the $\geq 400-\mathrm{km}$ scale is the bivalve Portlandia arctica, which is a very common benthic bivalve mollusk and endemic to the Arctic seas. This infaunal species prefers silty sediments and has first been described by J. E. Gray in 1824 (Gray 1824). The polychaete Leitoscoloplos mammosus is mostly structured on the intermediate $100-400-\mathrm{km}$ scale and occurs in Northern Atlantic and Arctic waters. This deposit feeder has been detected by A. S. Y. Mackie in 1987 and prefers the shelf as habitat at depths of around 25 -110 m (Mackie 1987). The taxon most associated with the small scale is the polychaete Antinoella sp. This genus was first described by H. Augener in 1928 when studying the polychaetes around Spitsbergen (Augener 1928). Antinoella sp. favors muddy and sandy sediments and is widely distributed in Arctic waters such as the Canadian Labrador Sea, Icy Cape of Alaska, Spitsbergen, Bering Sea and Kara Sea (Pettibone 1993). T. stroemii, as the most abundant species in the area, has been identified as presumably not being one single species but a large complex of unrevealed cryptic species (Hutchings and Kupriyanova 2018; Lavesque et al. 2019).

The three scales that we detected in our analysis describe spatial patterns over different distances within our area of investigation. The largest distance was $839 \mathrm{~km}$, suggesting that the $\geq 400-\mathrm{km}$ scale embraces assemblages over more than just one sea, e.g., Barents Sea to Kara Sea or Laptev Sea. The intermediate $100-400-\mathrm{km}$ scale refers to assemblage structures within a single sea. With $54 \mathrm{~km}$ as the smallest identified spatial distance, we suggest that the smallest $\leq 100-\mathrm{km}$ scale delineates patterns covering even smaller realms within single Arctic seas. With $\geq 400 \mathrm{~km}$ to $\leq 100 \mathrm{~km}$, the distance-range from the broadest to the smallest scale is relatively narrow in our case, while a comparable study from the sub-Arctic region could reveal regional differences on scales of several hundreds of kilometers down to $1 \mathrm{~km}$ (Silberberger et al. 2018). The sampling design always determines the range of spatial patterns detectable with such an analysis. We have a rather low sampling resolution, resulting in a relatively large smallest detectable scale.

The broad $\geq 400-\mathrm{km}$ scale patterns that MEM analysis identified in the distribution of macrobenthic communities basically reflect biogeographical contrasts exceeding the extent of the Laptev and Kara Sea, a spatial scale which matches ecoregions or large marine ecosystems (LME) (Solovyev et al. 2017). LME can be described as regional units for conservation and management approaches of living marine resources and are characterized by unique undersea topography, current dynamics, marine productivity, and food-web interactions (Sherman 1991; Solovyev et al. 2017). LMEs are known to best address conservation issues on a regional basis. However, the finding of our broad scale may demonstrate the limitation of applying LMEs. The environmental variables that were most correlated with the $\geq 400-\mathrm{km}$ scale patterns (Table 4 ) are proxies of benthic productivity/turnover (apparent oxygen utilization) and the strength of pelagic-benthic coupling (sediment phosphate content) (Table 4). These represent ecological differences along the longitudinal West-East gradient from sub-Arctic conditions and high-production regimes in the Barents Sea at one end to high-Arctic and low-production environments in the East Siberian Sea at the other end (Carmack and Wassmann 2006). The content of phosphate reflects sorption and desorption under different redox conditions. It is stored mostly in sediments and its release from sediment is provoked by the incapacity of the seafloor to absorb remobilized phosphate or by the high decomposition of organic matter at the sediment surface (Davenport et al. 2012; Link et al. 2013). The interconnection between bottom-near oxygen and distribution as well as activities of benthic macrofauna has already been substantiated earlier (Renaud et al. 2007; Kaskela et al. 2017).

The intermediate $100-400-\mathrm{km}$ scale patterns that are superimposed on the broad-scale gradients represent spatial faunistic and environmental differences within the ecoregions along mostly latitudinal South-North gradients in distances-to-shoreline and near-bottom temperature, as indicated by the ranking of environmental variables in the explanation of community variation on this scale range (Table 4). The distance-to-shoreline variable obtains its relevance for bottom communities by the strong impact of the Siberian river runoffs (Sirenko and Piepenburg 1994; Sirenko 2009). Coastal zones are usually dynamic harsh environments with high temporal variability, which are characterized by potential seasonal hypoxia, brackish water in bays, numerous small islands off the coast and gradients in bathymetry, salinity and nutrient levels (Deubel et al. 2003). Riverine influence causes the formation of stable benthic communities that are accustomed to a freshwater environment. A vast number of our sampling points especially in the Kara and Laptev Sea are located in coastal proximity. Via freshwater discharge and the transportation of riverine species the rivers $\mathrm{Ob}$ and Yenisei lead to the characteristic community composition along the shelf in the Kara Sea and the Lena river in the Laptev Sea, respectively. One species that was found to be abundant in brackish waters off the Siberian coast is the crustacean Saduria entomon, which is proved by the appearance of Saduria sp. in our results for the intermediate scale (Sirenko and Piepenburg 1994) (see Online Resource 6). Bottom temperature as the second most influential abiotic driver of benthic distribution patterns on this scale is known to be one crucial factor in determining general climate and hydrographic settings. Temperature is relatively restricted in its range in the Arctic Ocean and is proved to strongly 
influence benthic community composition due to its effect on metabolic rates which in turn impacts growth and nutrient recycling processes (Yasuhara et al. 2012; Grebmeier et al. 2015). Grebmeier et al. (2015) suggest that macrobenthic fauna have a wide-ranging spatial distribution within the Arctic Ocean. We found that variables which are proxies for pelagic-benthic coupling are mostly driving faunal assemblages on large and small spatial scales and to a less extent on mesoscales. However, we acknowledge that this can be different, depending on the region, and in other studies pelagic-benthic coupling has been demonstrated to be most important on mesoscales (Blanchard and Feder 2014). However, the association to a spatial scale may also depend the size range of the spatial scale, which in our case is rather large.

The small-scale patterns revealed in the MEM analysis refer to structures in biotic and abiotic data on spatial scales of less than $100 \mathrm{~km}$ that are superimposed on the mesoscale latitudinal gradients. They basically reflect the ecological impacts of oceanographic features (such as fronts, eddies or marginal ice zones) or shelf geomorphology (such as shallows or trenches) with spatial dimensions of tens of $\mathrm{km}$. In our study, such ecological impacts are primarily related to variation in general food availability for benthic communities and the environmental seafloor setting, as apparent in the relevance of environmental variables contributing to the explanation of small-scale spatial community structure (Table 4): carbon flux as a proxy of the strength of pelagic-benthic coupling and distance to shore. Organic carbon reaching the seafloor promotes high biomass, abundance and benthic biodiversity (Kędra et al. 2015). The distance-to-shoreline is due to the spatial extent of the influence of river discharge leading to an environmental setting influenced by riverine water and nutrients spread over larger areas than our smallest spatial range of around $50-100 \mathrm{~km}$.

The results of the variation partitioning to determine the individual contribution of environmental variables and spatial structure clearly demonstrated the predominant role of the environment in terms of community composition (Fig. 3). At each spatial scale range identified through MEM analysis, environmental variables were significantly explaining the variation in community composition (see $A d j R^{2}$ cum values in Table 4). Similar findings were accomplished by Henry et al. (2013) and Silberberger et al. (2018). However, the considerable residuals in our models indicate that a large extent of spatial structure in the communities cannot be completely explained by the used environmental variables (Fig. 3). This indicates the influence of unknown biotic or abiotic drivers, which also affect the abundance and composition of macrobenthic communities such as food availability, bacterial abundance, predator-prey interaction, iceberg scouring, sediment stability and sedimentation rate (Włodarska-Kowalczuk and Pearson 2004; Vedenin et al.
2018). One also needs to keep in mind that, the biotic data we used have not been taken at the same time. This introduces a bias due to temporal variability and could lead to a larger amount of unexplained spatial variability. Our overall results noticeably exemplify the impact the environment and its warming-induced changing dynamic have on marine ecosystems and its inhabitants, which makes it even more substantial to investigate these physio-biological interactions further.

\section{Conclusion and implications}

Ecological knowledge on the Eurasian-Arctic seas has increased substantially over the past years; however, only few investigations have related spatial variation in benthic communities to environmental settings at various scales. So, the comprehensive dissection of spatial scales and influential environmental factors governing species composition and distribution along the Eurasian-Arctic shelf zone is new information and fosters the understanding of physio-biological dynamics. The findings of our study indicate that distribution and composition of Eurasian-Arctic benthic communities are controlled by a variety of environmental determinants acting on multiple spatial scales. Our results are specific to the Eurasian-Arctic region (Barents, Kara and Laptev Sea) and are not meant to be extrapolated to a pan-Arctic scope, due to largely varying environmental conditions across the Arctic Ocean. This kind of information is needed for current climate politics and conservation management discussions to develop suitable preservation approaches, to plan the sustainable use of Arctic resources, to apply adaptation techniques to reduce risk and vulnerability and to declare future marine protected areas (MPAs) (IPCC 2019). Marine systems, and especially remote polar seas, are generally still underrepresented in the global network of marine protected areas (MPAs) (Spiridonov et al. 2011; Solovyev et al. 2017). Ecological consequences of the accelerating climate change become continuously more severe, making it even more critical to protect certain marine habitats by identifying and assigning potential conservation priority areas (CPAs) of high ecological value (Solovyev et al. 2017).

Acknowledgements We are grateful to the long-term German-Russian collaborative research project "The Changing Arctic Transpolar System" (CATS) and its scientific coordinator Heidemarie Kassens (Kiel), for making this study possible in the first place. The project was funded by the German Federal Ministry of Education and Research (BMBF).

Funding Open Access funding provided by Projekt DEAL. The research project "The Changing Arctic Transpolar System" (CATS) was funded by the German Federal Ministry of Education and Research (BMBF) under \# 03F0776. 
Code availability Please see Borcard D, Gillet F, Legendre P (2011) Numerical Ecology with R, $2^{\text {nd }}$ edn. Springer, New York Dordrecht London Heidelberg.

\section{Compliance with ethical standards}

Conflict of interest We do not declare any conflict of interests.

Availability of data and material The datasets generated and/or analyzed during the current study are available in the PANGAEA repository, https://doi.pangaea.de/10.1594/PANGAEA.910004 (dataset in review).

Open Access This article is licensed under a Creative Commons Attribution 4.0 International License, which permits use, sharing, adaptation, distribution and reproduction in any medium or format, as long as you give appropriate credit to the original author(s) and the source, provide a link to the Creative Commons licence, and indicate if changes were made. The images or other third party material in this article are included in the article's Creative Commons licence, unless indicated otherwise in a credit line to the material. If material is not included in the article's Creative Commons licence and your intended use is not permitted by statutory regulation or exceeds the permitted use, you will need to obtain permission directly from the copyright holder. To view a copy of this licence, visit http://creativecommons.org/licenses/by/4.0/.

\section{References}

Augener H (1928) Die Polychaeten von Spitzbergen. Fauna Arctica, Jena

Basher Z, Bowden DA, Costello MJ (2018) Global Marine Environment Datasets (GMED). World Wide Web electronic publication. Version 2.0 (Rev.02.2018). https://gmed.auckland.ac.nz. Accessed 17 June 2019

Bauman D, Drouet T, Fortin M-J, Dray S (2018) Optimizing the choice of a spatial weighting matrix in eigenvector-based methods. Ecology 99:2159-2166. https://doi.org/10.1002/ecy.2469

Behrenfeld MJ, Boss E, Siegel DA, Shea DM (2005) Carbon-based ocean productivity and phytoplankton physiology from space. Glob Biogeochem Cycles 19:1-14. https://doi.org/10.1029/2004G B002299

Bellier E, Monestiez P, Durbec JP, Candau JN (2007) Identifying spatial relationships at multiple scales: Principal coordinates of neighbour matrices (PCNM) and geostatistical approaches. Ecography 30:385-399. https://doi.org/10.1111/j.0906-7590.2007.04911.x

Benedetti-Cecchi L, Iken K, Konar B, Cruz-Motta J, Knowlton A, Pohle G, Castelli A, Tamburello L, Mead A, Trott T, Miloslavich P, Wong M, Shirayama Y, Lardicci C, Palomo G, Maggi E (2010) Spatial relationships between polychaete assemblages and environmental variables over broad geographical scales. PLoS ONE 5:1-10. https://doi.org/10.1371/journal.pone.0012946

Blanchet FG, Legendre P, Borcard D (2008) Forward selection of explanatory variables. Ecology 89:2623-2632. https://doi. org/10.1890/07-0986.1

Blanchard AL, Feder HM (2014) Interactions of habitat complexity and environmental characteristics with macrobenthic community structure at multiple spatial scales in the northeastern Chukchi Sea. Deep Sea Res I 102:132-143. https://doi.org/10.1016/j. dsr2.2013.09.022

Bluhm BA, Ambrose W, Bergmann M, Clough LM, Gebruk AV, Hasemann C, Iken K, Klages M, MacDonald IR, Renaud PE, Schewe I, Soltwedel T, Włodarska-Kowalczuk M (2011) Diversity of the arctic deep-sea benthos. Mar Biodivers 41:87-107. https://doi. org/10.1007/s12526-010-0078-4

Borcard D, Legendre P, Drapeau P (1992) Partialling out the spatial component of ecological variation. Ecology 73:1045-1055. https ://doi.org/10.2307/1940179

Borcard D, Legendre P (2002) All-scale spatial analysis of ecological data by means of principal coordinates of neighbour matrices. Ecol Model 153:51-68. https://doi.org/10.1016/S0304 $-3800(01) 00501-4$

Borcard D, Gillet F, Legendre P (2011) Numerical ecology with R, 2nd edn. Springer, New York

Budaeva NE, Mokievsky VO, Soltwedel T, Gebruk AV (2008) Horizontal distribution patterns in Arctic deep-sea macrobenthic communities. Deep Sea Res. Part I: Oceanographic Research Papers 55:1167-1178. https://doi.org/10.1016/j.dsr.2008.05.002

CAFF (2017) State of the Arctic Marine Biodiversity Report. Conservation of Arctic Flora and Fauna International Secretariat, Akureyri, Iceland

Carmack E, Wassmann P (2006) Food webs and physical-biological coupling on pan-Arctic shelves: Unifying concepts and comprehensive perspectives. Progr Oceanogr 71:446-477. https://doi. org/10.1016/j.pocean.2006.10.004

Carroll ML, Denisenko SG, Renaud PE, Ambrose WG (2008) Benthic infauna of the seasonally ice-covered western Barents Sea: Patterns and relationships to environmental forcing. Deep Sea Res II 55:2340-2351. https://doi.org/10.1016/j. dsr2.2008.05.022

Cochrane SKJ, Pearson TH, Greenacre M, Costelloe J, Ellingsen IH, Dahle S, Gulliksen B (2009) Benthic fauna and functional traits along a Polar Front transect in the Barents Sea-advancing tools for ecosystem-scale assessments. J Mar Syst 94:204-217. https:// doi.org/10.1016/j.jmarsys.2011.12.001

Davenport ES, Shull DH, Devol AH (2012) Roles of sorption and tubedwelling benthos in the cycling of phosphorus in Bering Sea sediments. Deep Sea Res II 65-70:163-172. https://doi.org/10.1016/j. dsr2.2012.02.004

Deubel H, Engel M, Fetzer I, Gagaev S, Hirche H-J, Klages M, Larionov V, Lubin P, Lubina O, Nöthig E-M, Okolodkov Y, Rachor E (2003) The southern Kara Sea ecosystem: Phytoplankton, zooplankton and benthos communities influenced by river run-off. In: Stein R, Fahl K, Fütterer DK, Galimov EM, Stepanets OV (eds) Proceedings in Marine Science: Siberian river run-off in the Kara Sea, Volume 6, 1st edn. Elsevier, Moscow, pp 237-265

Dilman AB (2009) Biogeography of sea stars of the North Atlantic and Arctic. Dissertation, University of St. Petersburg

Doney S, Ruckelshaus M, Duffy JE, Barry JP, Chan F, English CA, Galindo HM, Grebmeier JM, Hollowed AB, Knowlton N, Polovina J, Rabalais NN, Sydeman WJ, Talley LD (2012) Climate change impacts on marine ecosystems. Annu Rev Mar Sci 4:11-37

Dray S, Legendre P, Peres-Neto PR (2006) Spatial modelling: a comprehensive framework for principal coordinate analysis of neighbour matrices (PCNM). Ecol Model 196:483-493. https://doi. org/10.1016/j.ecolmodel.2006.02.015

Dray S, Pélissier R, Couteron P, Fortin M-J, Legendre P, Peres-Neto PR, Bellier E, Bivand R, Blanchet G, de Cáceres M, Dufour A-B, Heegaard E, Jombart T, Munoz F, Oksanen J, Thioulouse J, Wagner HH (2012) Community ecology in the age of multivariate spatial analysis. Ecol Monogr 82:257-275. https://doi. org/10.1890/11-1183.1

Dray S, Bauman D, Blanchet G, Borcard D, Clappe S, Guenard G, Jombart T, Larocque G, Legendre P, Madi N, Wagner HH (2019) Package 'adespatial'. Multivariate Multiscale Spatial Analysis. https://cran.r-project.org/web/packages/adespatial/adespatial.pdf. Accessed 17 June 2019 
Galkin SV, Vedenin AA (2015) Macrobenthos of Yenisei Bay and the adjacent Kara Sea shelf. Oceanology 55:606-613. https://doi. org/10.1134/S0001437015040086

Garcia HE, Weathers K, Paver CR, Smolyar I, Boyer TP, Locarnini RA, Zweng MM, Mishonov AV, Baranova OK, Reagan JR (2018a) World Ocean Atlas 2018, Volume 4: Dissolved Inorganic Nutrients (phosphate, nitrate, silicate). A. Mishonov Technical Ed. https ://www.nodc.noaa.gov/OC5/woa18/woa18data.html. Accessed 17 June 2019

Garcia HE, Weathers K, Paver CR, Smolyar I, Boyer TP, Locarnini RA, Zweng MM, Mishonov AV, Baranova OK, Reagan JR (2018b) World Ocean Atlas 2018, Volume 3: Dissolved Oxygen, Apparent Oxygen Utilization, and Oxygen Saturation. A. Mishonov Technical Ed. https://www.nodc.noaa.gov/OC5/woa18/woa18data.html. Accessed 17 June 2019

Gordeev VV, Martin JM, Sidorov IS, Sidorova MV (1996) A reassessment of the Eurasian river input of water, sediment, major elements, and nutrients of the Arctic Ocean. Am J Sci 296:664-691. https://doi.org/10.2475/ajs.296.6.664

Gray J E (1824) Shells. In: Parry WE (ed) Supplement to Appendix, Parry's Voyage for the Discovery of a north-west passage in the years 1819-1820, containing an account of the subjects of Natural History London, John Murray. Appendix 10, Zool:240-246

Grebmeier JM, Bluhm BA, Cooper LW et al (2015) Ecosystem characteristics and processes facilitating persistent macrobenthic biomass hotspots and associated benthivory in the Pacific Arctic. Progr Oceanogr 136:92-114. https://doi.org/10.1016/j.pocea n.2015.05.006

Gutt J, Arndt J, Kraan C, Dorschel B, Schröder M, Bracher A, Piepenburg D (2019) Benthic communities and their drivers: a spatial analysis off the Antarctic Peninsula. Limnol Oceanogr 62:23412357. https://doi.org/10.1002/lno.11187

Henry LA, Moreno Navas J, Roberts JM (2013) Multi-scale interactions between local hydrography, seabed topography, and community assembly on cold-water coral reefs. Biogeosciences 10:27372746. https://doi.org/10.5194/bg-10-2737-2013

Hutchings P, Kupriyanova E (2018) Cosmopolitan polychaetes-fact or fiction? Personal and historical perspectives. Invertebr Syst 32:1-9. https://doi.org/10.1071/IS17035

Ingels J, Vanreusel A (2013) The importance of different spatial scales in determining structural and functional characteristics of deepsea infauna communities. Biogeosciences 10:4547-4563. https:// doi.org/10.5194/bg-10-4547-2013

IPCC (2019) Polar regions. In: IPCC Special Report on the Ocean and Cryosphere in a Changing Climate [Pörtner H-O, Roberts DC, Masson-Delmotte V, Zhai P, Tignor M, Poloczanska E, Mintenbeck K, Alegría A, Nicolai M, Okem A, Petzold J, Rama B, Weyer NM (eds.)].

Jakobsson M, Mayer L, Coakley B, Dowdeswell JA, Forbes S, Fridman B, Hodnesdal H, Noormets R, Pedersen R, Rebesco M, Schenke HW, Zarayskaya Y, Accettella D, Armstrong A, Anderson RM, Bienhoff P, Camerlenghi A, Church I, Edwards M, Gardner JV, Hall JK, Hell B, Hestvik O, Kristoffersen Y, Marcussen C, Mohammad R, Mosher D, Sv N, Pedrosa MT, Travaglini PG, Weatherall P (2012) The International Bathymetric Chart of the Arctic Ocean (IBCAO) Version 3.0. Geophys Res Lett 39:1-6. https://doi.org/10.1029/2012GL052219

Jirkov IA (2013) Biogeography of the Barents Sea benthos. Invert Zool $1: 69-88$

Jombart T, Dray S, Dufour AB (2009) Finding essential scales of spatial variation in ecological data: a multivariate approach. Ecography 32:161-168. https://doi.org/10.1111/j.1600-0587.2008.05567 .x

Jørgensen LL, Pearson TH, Anisimova NA, Gulliksen B, Dahle S, Denisenko SG, Matishov GG (1999) Environmental influences on benthic fauna associations of the Kara Sea (Arctic Russia). Polar Biol 22:395-416. https://doi.org/10.1007/s003000050435

Kaskela AM, Rousi H, Ronkainen M, Orlova M, Babin A, Gogoberidze G, Kostamo K, Kotilainen AT, Neevin I, Ryabchuk D, Sergeev A, Zhamoida V (2017) Linkages between benthic assemblages and physical environmental factors: the role of geodiversity in Eastern Gulf of Finland ecosystems. Cont Shelf Res 142:1-13. https://doi. org/10.1016/j.csr.2017.05.013

Kędra M, Moritz C, Choy ES (2015) Status and trends in the structure of Arctic benthic food webs. Polar Res 34:1-23. https://doi. org/10.3402/polar.v34.23775

Kokarev VN, Vedenin AA, Basin AB, Azovsky AI (2017) Taxonomic and functional patterns of macrobenthic communities on a highArctic shelf: a case study from the Laptev Sea. J Sea Res 129:6169. https://doi.org/10.1016/j.seares.2017.08.011

Lavesque N, Hutchings P, Daffe G, Nygren A, Londoño-Mesa MH (2019) A revision of the French Trichobranchidae (Polychaeta), with descriptions of nine new species. Zootaxa 4664:151-190

Legendre P (1993) Spatial autocorrelation: trouble or new paradigm. Ecology 74:1659-1673. https://doi.org/10.2307/1939924

Legendre P, Legendre L (2012) Numerical Ecology, 3rd edn. Elsevier, Amsterdam

Levin SA (1992) The problem of pattern and scale in ecology. Ecology 73:1943-1967. https://doi.org/10.2307/1941447

Link H, Chaillou G, Forest A, Piepenburg D, Archambault P (2013) Multivariate benthic ecosystem functioning in the Arctic-benthic fluxes explained by environmental parameters in the southeastern Beaufort Sea. Biogeosciences 10:5911-5929. https://doi. org/10.5194/bg-10-5911-2013

Locarnini RA, Mishonov AV, Baranova OK, Boyer TP, Zweng MM, Garcia HE, Reagan JR, Seidov D, Weathers K, Paver CR, Smolyar I (2018) World Ocean Atlas 2018, Volume 1: Temperature. A. Mishonov Technical Ed. https://www.nodc.noaa.gov/OC5/woa18 /woa18data.html. Accessed 17 June 2019

Macias-Fauria M, Post E (2018) Effects of sea ice on Arctic biota: an emerging crisis discipline. Biol Lett 14:1-7. https://doi. org/10.1098/rsbl.2017.0702

Mackie ASY (1987) A review of species currently assigned to the genus Leitoscoloplos day, 1977 (polychaeta: Orbiniidae), with descriptions of species newly referred to Scoloplos Blainville, 1828. Sarsia 72:1-28. https://doi.org/10.1080/00364827.1987.10419701

Oksanen J, Blanchet FG, Friendly M, Kindt R, Legendre P, McGlinn D, Minchin PR, O'Hara RB, Simpson GL, Solymos P, Stevens MHH, Szoecs E, Wagner H (2019) Package 'vegan'. Community Ecology Package. https://cran.r-project.org/web/packages/vegan/ vegan.pdf. Accessed 17 June 2019

Pantiukhin D, Popova E, Piepenburg D, Kraan C (2019) Grain-size distribution in surficial seafloor sediments of Eurasian Arctic seas. PANGAEA https://doi.pangaea.de/10.1594/PANGAEA.909392 (dataset in review). Accessed 17 June 2019

Peres-Neto PR, Legendre P, Dray S, Borcard D (2006) Variation partitioning of taxa data matrices: estimation and comparison of fractions. Ecology 87:2614-2625. https://doi. org/10.1007/978-94-007-0394-0_3

Peres-Neto PR, Legendre P (2010) Estimating and controlling for spatial structure in the study of ecological communities. Glob Ecol Biogeogr 19:174-184. https://doi.org/10.111 1/j.1466-8238.2009.00506.x

Pettibone MH (1993) Revision of some species referred to Antinoe, Antinoella, Antinoana, Bylgides, and Harmothoe (Polychaeta: Polynoidae: Harmothoinae). Smithson Contrib Zool 545:1-41. https://doi.org/10.5479/si.00810282.545

Piepenburg D, Archambault P, Ambrose WG, Blanchard AL, Bluhm BA, Carroll ML, Conlan KE, Cusson M, Feder HM, Grebmeier JM, Jewett SC, Lévesque M, Petryashev VV, Sejr MK, Sirenko BI, Włodarska-Kowalczuk M (2011) Towards a pan-Arctic 
inventory of the species diversity of the macro- and megabenthic fauna of the Arctic shelf seas. Mar Biodivers 41:51-70. https:// doi.org/10.1007/s12526-010-0059-7\%0A

R Development Core Team (2017) R: A language and environment for statistical computing. R Foundation for Statistical Computing. https://www.R-project.org/. Accessed 17 June 2019

Renaud PE, Włodarska-Kowalczuk M, Trannum H, Holte B, Węsławski JM, Cochrane S, Dahle S, Gulliksen B (2007) Multidecadal stability of benthic community structure in a high-Arctic glacial fjord (van Mijenfjord, Spitsbergen). Polar Biol 30:295-305. https://doi. org/10.1007/s00300-006-0183-9

Renaud PE, Sejr MK, Bluhm BA, Sirenko BI, Ellingsen IH (2015) The future of Arctic benthos: expansion, invasion, and biodiversity. Progr Oceanogr 139:244-257. https://doi.org/10.1016/j.pocea n.2015.07.007\%0A

Roy V, Iken K, Archambault P (2014) Regional variability of megabenthic community structure across the Canadian Arctic. Arctic 68:180-192

Rudels B (2012) Arctic Ocean circulation and variability - advection and external forcing encounter constraints and local processes. Ocean Sci 8:261-286. https://doi.org/10.5194/os-8-261-2012

Sherman K (1991) The large marine ecosystem concept: Research and management strategy for living marine resources. Ecol Appl 1:349-360. https://doi.org/10.2307/1941896

Silberberger MJ, Renaud PE, Espinasse B, Reiss H (2016) Spatial and temporal structure of the meroplankton community in a subArctic shelf system. Mar Ecol Prog Ser 555:79-93. https://doi. org/10.3354/meps 11818

Silberberger MJ, Renaud PE, Buhl-Mortensen L, Ellingsen IH, Reiss H (2018) Spatial patterns in sub-Arctic benthos: multiscale analysis reveals structural differences between community components. Ecol Monogr 89:1-22. https://doi.org/10.1002/ecm.1325

Sirenko BI (2001) List of species of free-living invertebrates of Eurasian Arctic seas and adjacent deep waters. Explor Fauna Seas 51:5-10

Sirenko BI (2009) Main differences in macrobenthos and benthic communities of the Arctic and Antarctic, as illustrated by comparison of the Laptev and Weddell sea faunas. Russ J Mar Biol 35:445453. https://doi.org/10.1134/S1063074009060017

Sirenko BI, Piepenburg D (1994) Current knowledge on biodiversity and faunal zonation patterns of the shelf of the seas of the Eurasian Arctic, with special reference to the Laptev Sea. Rep Polar Res 144:69-74

Sirenko BI, Denisenko S, Deubel H, Rachor E (2004) Deep water communities of the Laptev Sea and adjacent parts of the Arctic Ocean. Fauna and the ecosystems of the Laptev Sea and adjacent deep waters of the Arctic Ocean. Explorations of the fauna of Sea. St. Petersburg: Zoological Institute of Russian Academy of Sciences, 54: $28-73$.
Solovyev B, Soiridonov V, Onufrenya I et al (2017) Identifying a network of priority areas for conservation in the Arctic seas: practical lessons from Russia. Aquatic Conserv Mar Freshw Ecosyst 27:30-51. https://doi.org/10.1002/aqc.2806

Spiridonov VA, Gavrilo MV, Krasnova ED, Nikolaeva NG (2011) The Atlas of the marine and coastal biological diversity of the Russian Arctic. Atlas of marine and coastal biological diversity of the Russian Arctic. WWF Russia, Moscow

Steele M, Ermold W, Zhang J (2008) Arctic Ocean surface warming trends over the past 100 years. Geophy Res Lett 35:1-6. https:// doi.org/10.1029/2007GL031651

Suess E (1980) Particulate organic Carbon flux in the oceans-surface productivity and oxygen utilization. Nature 288:260-263. https:// doi.org/10.1038/288260a0

Vedenin AA, Galkin SV, Kozlovskiy VV (2015) Macrobenthos of the Ob Bay and adjacent Kara Sea shelf. Polar Biol 38:829-844. https ://doi.org/10.1007/s00300-014-1642-3

Vedenin AA, Gusky M, Gebruk AV, Kremenetskaia A, Rybakova E, Boetius A (2018) Spatial distribution of benthic macrofauna in the Central Arctic Ocean. PLoS ONE 13:1-23. https://doi. org/10.1371/journal.pone.0200121

Walsh JE, Fetterer F, Stewart JS, Chapman WL (2017) A database for depicting Arctic sea ice variations back to 1850 . Geogr Rev 107:89-107. https://doi.org/10.1111/j.1931-0846.2016.12195.x

Włodarska-Kowalczuk M, Pearson TH (2004) Soft-bottom macrobenthic faunal associations and factors affecting species distributions in an Arctic glacial fjord (Kongsfjord, Spitsbergen). Polar Biol 27:155. https://doi.org/10.1007/s00300-003-0568-y

Woodgate RA (2018) Increases in the Pacific inflow to the Arctic from 1990 to 2015, and insights into seasonal trends and driving mechanisms from year-round Bering Strait mooring data. Progr Oceanogr 160:124-154. https://doi.org/10.1016/j.pocean.2017.12.007

Yasuhara M, Hunt G, van Dijken G, Arrigo KR, Cronin TM, Wollenburg JE (2012) Patterns and controlling factors of species diversity in the Arctic Ocean. J Biogeogr 39:2081-2088. https://doi.org/10 $.1111 / \mathrm{j} .1365-2699.2012 .02758 . x$

Zenkevitch LA (1963) Biology of the seas of the U.S.S.R. Allen \& Unwin, London

Zweng MM, Reagan JR, Seidov D, Boyer TP, Locarnini RA, Garcia HE, Mishonov AV, Baranova OK, Weathers K, Paver CR, Smolyar I (2018) World Ocean Atlas 2018, Volume 2: Salinity. A. Mishonov Technical Ed. https://www.nodc.noaa.gov/OC5/woa18 /woa18data.html. Accessed 17 June 2019

Publisher's Note Springer Nature remains neutral with regard to jurisdictional claims in published maps and institutional affiliations. 